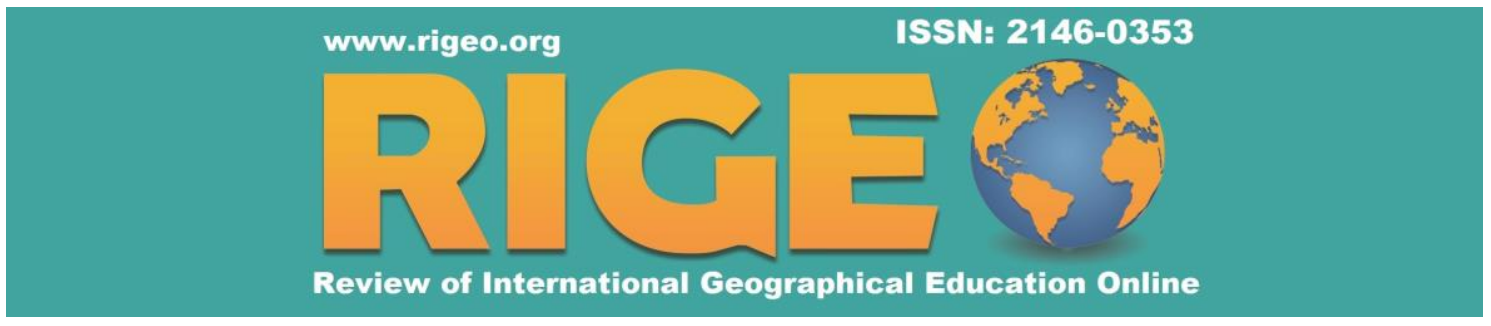

Review of International Geographical Education Online

(C) RIGEO Volume 9, Number 2, Summer 2019

Research Article

Copyright @ RIGEO 2019

To cite this article: Rakytová, I., Tomčíková, I. (2019). Using UNESCO world heritage site of VIkolínec (Slovakia) in geopraphical education. Review of International Geographical Education Online (RIGEO), 9(2), 426-446. Retrieved from http://www.rigeo.org/vol9no2/Number2Summer/RIGEO-V9-N2-8.pdf

DOI: 10.33403 /rigeo.573655

Submitted: June 3, $2019 \quad$ Revised: August 6, $2019 \quad$ Accepted: August 17, 2019

\title{
Using UNESCO World Heritage Site of VIkolínec (Slovakia) in Geographical Education
}

\author{
Iveta RAKYTOVÁ ${ }^{1}$ \\ Catholic University in Ruzomberok, SLOVAKIA \\ Ivana TOMČÍKOVÁ 2 \\ Catholic University in Ruzomberok, SLOVAKIA
}

\begin{abstract}
UNESCO identifies unique places in the World, whether natural or man-made, of universally outstanding value or cultural significance as World Heritage. These places are considered heritage of all mankind, rather than just heritage of a particular area, country, or region. Such sites can be rich sources of information not only for the people of the region, but also for the general public, and are often associated with lively tourism. The aim of this paper is to characterize the UNESCO World Heritage site of Vlkolínec, one of the most visited UNESCO sites in Slovak Republic, and to use the settlement of Vlkolínec as an example to describe how the site attributes can be used in geographical education. In the first part of the paper, we describe the natural potential of Vlkolínec, characterize the settlement's development from the end of the 18th century to the present, and describe historical landscape structures whose existence in Vlkolínec was the reason for its inscription on the UNESCO World Heritage List. In the school year 2018/2019, we conducted a survey among students in the 2nd stage of primary school in Liptov region on their knowledge about the UNESCO site of Vlkolínec. Based on the results of the survey, we designed and realized a project with eighth class primary students at the Slovak UNESCO World Heritage site of Vlkolínec.
\end{abstract}

\section{Keywords}

UNESCO site; Geographical Education; Project Teaching; Field Trip

In today's interconnected world, culture's power to transform societies is visible. Its diverse manifestations-from historic monuments and museums to traditional practices of land use - enrich our everyday lives in countless ways. Heritage constitutes a source

${ }^{1}$ Corrospending Author; Ph.D., Hrabovská cesta 1, Ružomberok, Slovakia, iveta.rakytova [at] ku.sk, ORCID: 0000-0003-36176633

2Ph.D., Hrabovská cesta 1, Ružomberok,Slovakia, ivana.tomcikova [at] ku.sk, ORCID: 0000-0003-2291-6872

(C) Review of International Geographical Education Online RIGEO 2019 ISSN: 2146-0353 
of identity and cohesion for communities disrupted by change and economic instability in the World. Heritage lays the foundation for vibrant, innovative and prosperous societies.

What makes the concept of World Heritage exceptional is its universal application. We can say that World Heritage sites belong to all the peoples of the world, irrespective of the territory on which they are located. We just have to agree with the idea that is posted on the UNESCO website that: "Heritage is our legacy from the past, what we live with today, and what we pass on to future generations. Our cultural and natural heritages are both irreplaceable sources of life and inspiration“(UNESCO, 2019).

Slovakia is a small country, in terms of its area, located in the centre of Europe where there are many natural and cultural beauties and attractions. Those that are of unique world value and are in need of their protection and preservation for future generations have been included in the UNESCO List of World Cultural and Natural Heritage Sites.

There are seven Slovak sites inscribed on the World Heritage List - five of them are of cultural and two of natural origin. Cultural sites of Slovakia inscribed on the World Heritage List include the historic town of Banská Štiavnica and the Technical Monuments in its Vicinity (since 1993), Levoča, Spišský Hrad and the Associated Cultural Monuments (since 1993, extended in 2009), Vlkolínec (since 1993), Bardejov Town Conservation Reserve (since 2000) and Wooden Churches of the Slovak part of the Carpathian Mountain Area (since 2008) (Figure 1).

Natural sites of Slovakia inscribed on the World Heritage List include the Caves of Aggtelek Karst and Slovak Karst - Slovak and Hungarian transboundary property (since 1995, extended in 2000) and Primeval Beech Forests of the Carpathians and the Ancient Beech Forests of Germany-Slovak-Ukrainian-German transboundary property (since 2007, extended in 2011). 


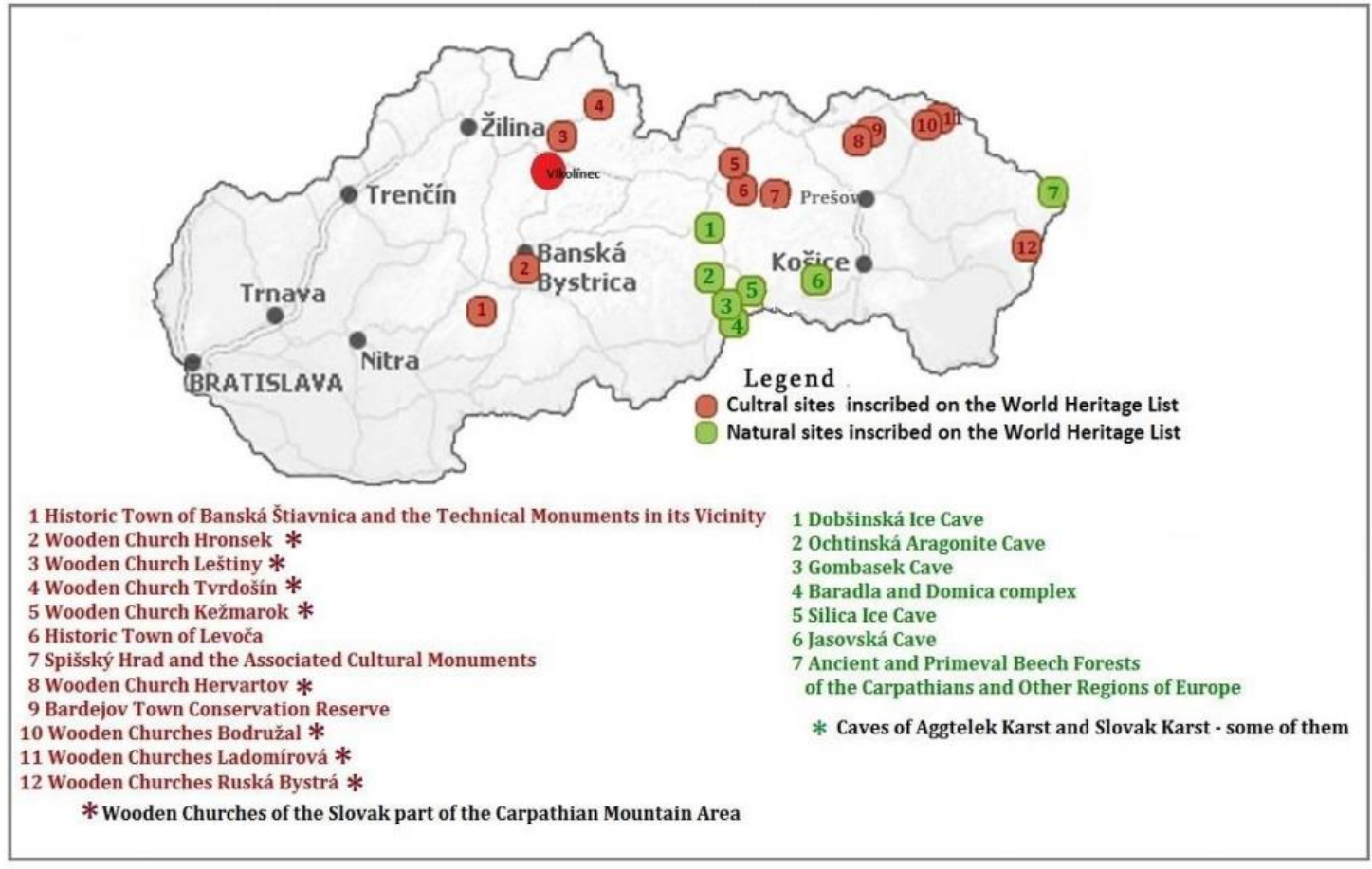

Figure 1. UNESCO World Heritage Sites on the map of Slovakia (Source: www.slovakiatravel.sk, edited by authors)

\section{Background}

This study has two aims: to characterize the UNESCO World Heritage site of Vlkolínec, one of the most visited UNESCO sites in the Slovak Republic, and to use the settlement of Vlkolínec as an example to describe how the site attributes can be used in geographical education. With regard to ISCED (geography) for primary school, it is stated that the pupil should be able to appoint the registered sites of UNESCO Word Heritage, substantiate their inclusion on the UNESCO Word Heritage List and show them on the map (ISCED, 2014).

Definition of the area, natural potential and development of the settlement of the UNESCO locality Vlkolínec, and identification of structures and values in the given territory were processed according to available literature, from data provided to us by employees of the Ružomberok Municipal Office and from data obtained from the Regional Administration of the Statistical Office of the Slovak Republic. The main publications were the works of local authors Bábal (2002) and Svrček et al. (2008, 2014). These authors come from the analyzed territory and their work provides important geographic and historical information about the analyzed area.

Vlkolínec was inscribed on the UNESCO World Heritage List in Cartagena in December 1993 on the basis of fourth and fifth selection criteria. The fourth criterion represents unique examples of types of buildings, architectural and technical ensembles or landscapes which illustrate significant stages in human history. The fifth criterion includes unique examples of traditional human settlements and land-use which are 
representative of cultures or human interactions with the environment especially when it has become vulnerable under the impact of irreversible change.

The settlement, which was mentioned for the first time in 1376, is the only one in Slovakia that has not been affected by new construction and represents a unique urban unit of original folk buildings. Based on a comparative study by ICOMOS (International Council on Monuments and Sites), it was evaluated as the best preserved settlement of this type in the Carpathian Arc. It was originally a woodcutters', shepherds' and farmers' settlement. At present, it is a lively settlement with people who have their own demands and standard of living. Therefore, it is necessary to propose further development of the site in a way that would preserve the cultural, natural and landscape values, but also respect the needs of the owners of the buildings.

Gullino, Larcher (2013), who in their study focused on rural landscape and its meaning for UNESCO Heritage, demonstrated that UNESCO assigns a high value to the following parameters: historical features, traditional crops and local products, landuse and agricultural practice permanence, and presence of architecture related to agricultural activity. They found the relationship between culture and nature to best characterize the integrity of a rural landscape, rather than nature or culture alone. UNESCO monuments are heavily influenced by tourism, whether in a positive or negative sense. A similar view in their contribution present Koca and Yildirim (2018). They think that tourism has many positive and negative effects due to changes in the economic, social, and cultural structure of the country or region in which it is located and the community.

The State Educational Scheme in Slovakia designates teaching subjects that are integrated into individual learning areas. Geography is included in the Man and Society area. It is grouped together with history and social studies. The main aim of this educational area is to introduce students to the evolution of human society using the most important social phenomena and processes, which are reflected into everyday life, and to perceive the World integrally as the mutual relationship between Man and society in a given geographical area (Rakytová, 2018).

The aim of teaching Geography at Slovak schools is to develop students' knowledge, skills and competences that are applicable not only at school but also in everyday life. Students need to learn to think, create, consider, evaluate and respond to the results of their work. These objectives can be met if traditional teaching based on memorization of large amounts of information is replaced by teaching focused on individual and creative activity of students during lessons. It is necessary to realize that knowledge of facts is in itself worthless without mastering the ability to synthesise, integrate and evaluate (some facts-based tasks only require awareness of content). Meaningful learning is a learning in which learners think about new knowledge, engage in discussion and seek solutions. Only then will their new experiences become basis for knowledge (Tomčíková, Rakytová, 2018).

The UNESCO natural and cultural monuments on the list of World Heritage are part of standard content for the subject of Geography in every grade of primary school. The 
content does not only cover UNESCO sights in Slovakia (these are taught in the 8th grade of primary school), but also about World Heritage sites in the World.

\section{Methodology}

This study consists of two parts. The first part is focused on the characteristics of the UNESCO site Vlkolínec. The second part looks for and explores possibilities of its use in teaching Geography in primary schools.

The natural potential of the Vlkolínec locality, the settlement's development from the end of the 18th century to the present, and the historical landscape structures that are in Vlkolínec were processed according to available literature and data obtained from the Regional Administration of the Statistical Office of the Slovak Republic.

The subjects of the research are pupils studying in primary schools in Liptov region (districts of Ružomberok and Liptovský Mikuláš). Vlkolínec is located in the Liptov region, so we wanted to find out what knowledge students have about this UNESCO World Heritage site located in their region (Figure 2).

At the beginning of the school year 2018/2019, we conducted a survey about the UNESCO World Heritage site of Vlkolínec in the form of a questionnaire. The questionnaire comprised of 8 questions and 180 students in 16 primary schools in Liptov responded to it. 


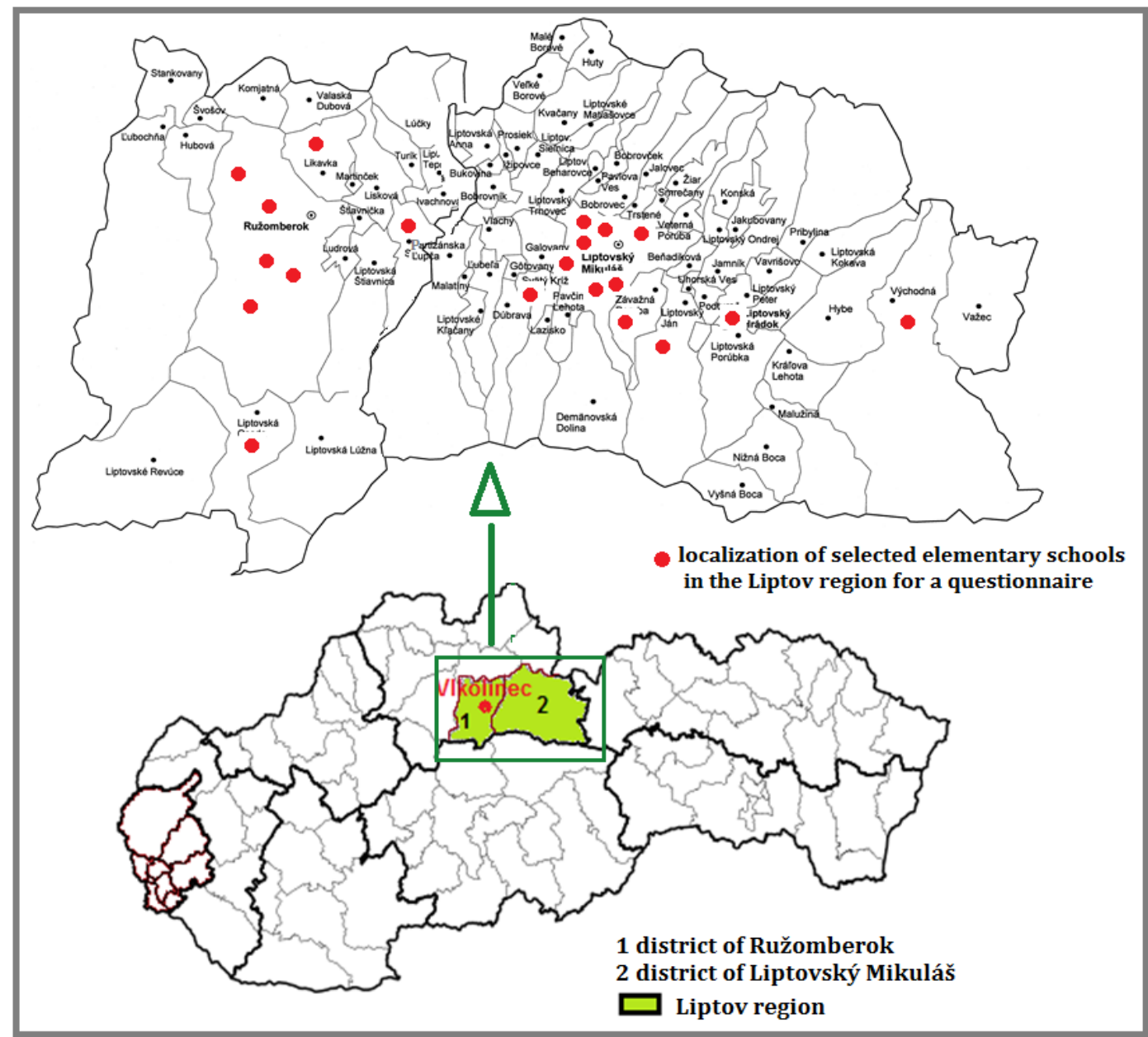

Figure 2. The Liptov region - Area of study for survey in primary schools (Source: edited by authors)

Based on the results of the survey, we designed and realized a project with year eight primary students at the Slovak UNESCO World Heritage site of Vlkolínec. A good way to acquire the desired knowledge is to visit the site and the most appropriate organizational form in this case was a one-day excursion to Vlkolínec. We decided to apply project teaching to validate the acquired knowledge.

\section{Characteristics of UNESCO site VIkolínec in Slovakia}

\section{Natural Potential of VIkolínec}

Vlkolínec is a part of the municipal district town of Ružomberok, located in the Vel'ká Fatra mountains at an altitude of $718 \mathrm{~m}$ a. s. 1. at the southern foot of the hill of Sidorovo (1,099 $\mathrm{m}$ above sea level) (Figure 3). 


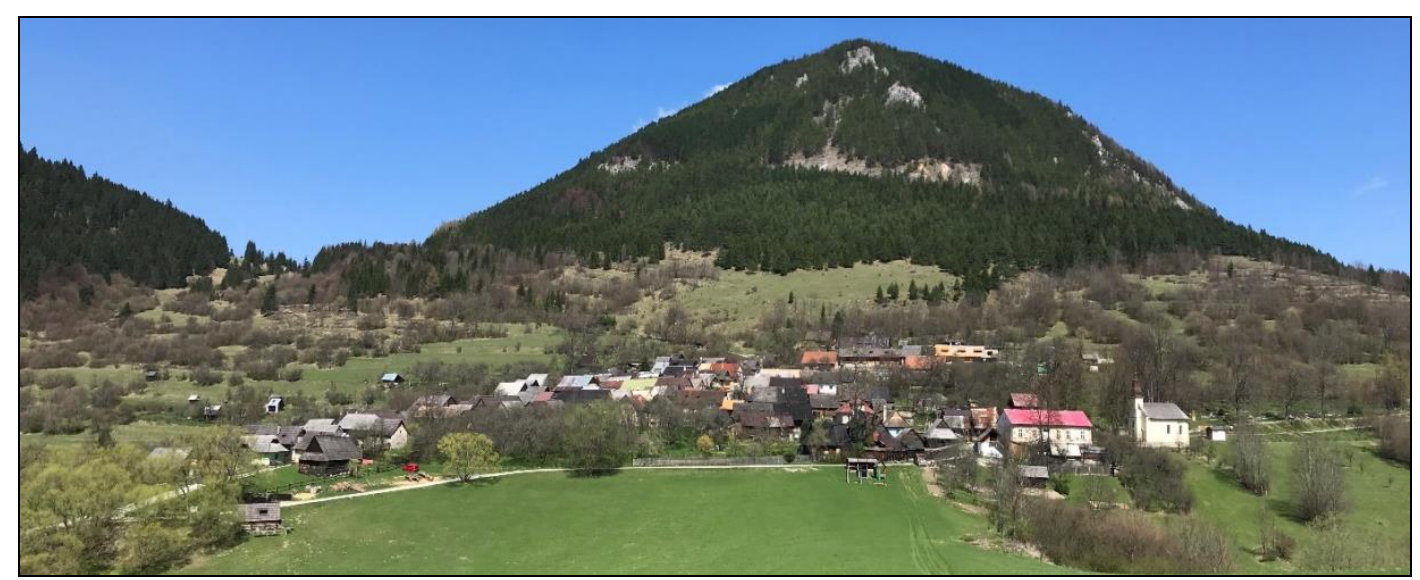

Figure 3. Sidorovo hill with Vlkolínec (Source: authors)

From a geological point of view, the core mountain of Vel'ká Fatra consists of paleogene horsts, areas that are limited by grabens. The crystalline core, which rises to the surface, is formed by transformed and granitoid rocks. The core is enclosed with a mantle consisting of mostly Mesozoic rocks, limestones and dolomites (Dzuriak et al., 2014).

Vlkolínec lies on the border of two climatic areas - a slightly temperate area and a cold area. The warmest month is July, with an average temperature of about $14.1^{\circ} \mathrm{C}$. On the contrary, the coldest month is January, with an average temperature of $-5.7^{\circ} \mathrm{C}$. The average annual rainfall is approximately $900 \mathrm{~mm}$. Northeast and Eastern winds, as well as Southern winds, prevail. The studied area is protected from Northern winds by Sidorovo hill, and from Western winds by Borovník and Malinné hills.

A stream that flows through Vlkolínec forms the settlement's axis, drawn from a road to gardens in the central part of the village. It is lined by a road on both sides. The stream's water distribution is contained in wooden chutes with a diameter of $40 \mathrm{~cm}$. The stream then flows into Trlenský stream, which flows into Revúca River.

In the vicinity of the settlement of Vlkolínec, we can find predominantly sand-clay and silt-clay soil types. Regarding soil types, mainly rendzic leptosols are spread on carbonate rocks and cambisols on eroded flysch.

According to the phytogeographical division of Europe (Plesník, 2002), Vlkolínec region belongs to the Holarctic region, the Euro-West-Siberian subregion and the Central European province. According to the phytogeographical division of Slovakia, the territory belongs to the area of Western Carpathian Flora (Carpaticum occidentale), to the region of High Carpathians (Eucarpaticum), to the district of Fatra and the subdistrict of Vel'ká Fatra. Vertical vegetation zones present at this area range from beech forest, fir-beech, spruce-beech-fir to spruce zones.

According to the zoogeographical division of Slovakia, the area belongs to the Arctogea region, Palaearctic subregion and forest zone.

There are several protected natural sites in the surroundings of the settlement of Vlkolínec. Protection of the studied area's nature has been exercised since 1974, when 
the Vel'ká Fatra Protected Landscape Area was declared. At present, it is practiced under the National Park of Vel'ká Fatra. In close proximity to the settlement of Vlkolínec, there are three natural monuments - Dogerske Rocks (which reveal limestone layers from the Mesozoic Era), Krkava Rock (a fifteen-meter high rock, which originated from the mesozoic eroded dolomites) and Wolf Rock (travertine terrace from the Quarternary period) (Figure 4).

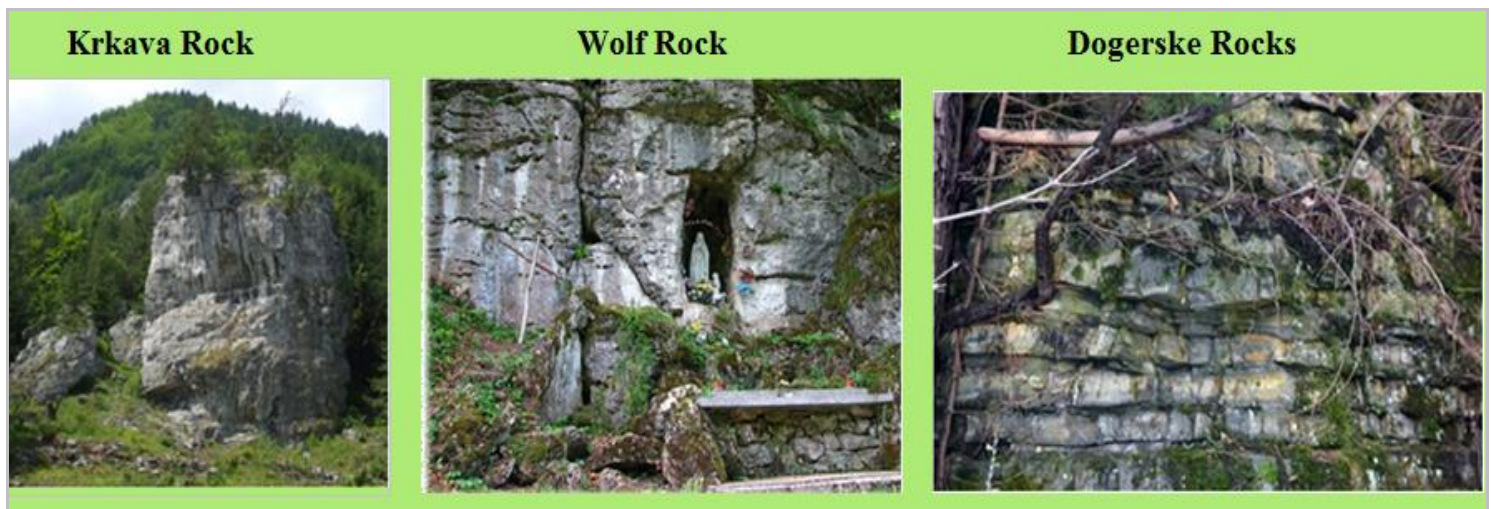

Figure 4. Three natural monuments in close proximity to the settlement of Vlkolínec (Source: authors)

\section{Development of the settlement of VIkolínec}

The first written mention of the settlement dates back to 1461. As in the past, it is still a part of the town of Ružomberok. Ružomberok was declared a town in 1318 and it subsequently embraced several municipalities in the 14th century. One of them was the settlement of Vlkolínec. It was probably built as a charcoal manufacturers' and woodcutters' settlement by inhabitants of Biely Potok.

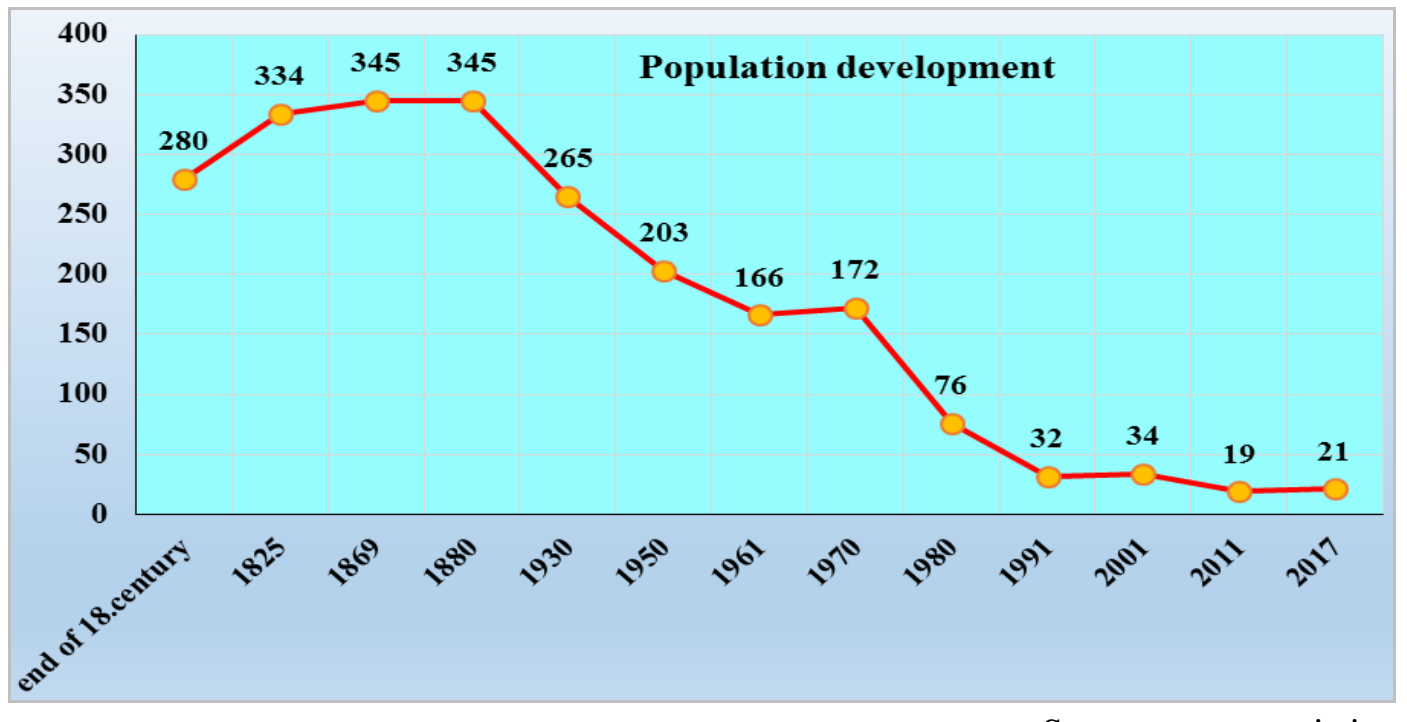

Figure 5. Population development according to available statistical sources

Source: www.statistics.sk

The first known population census of 1766 indicates that 117 people lived in the settlement. The settlement reached its largest number of inhabitants - 345 - in 1869. 
Since then, the population has been constantly decreasing and nowadays there are 21 inhabitants residing in the settlement (Figure 5).

From the settlement development point of view, it is a slope settlement situated at the foot of the hill of Sidorovo. It is made up of one central street which is further branching out in its southern part. The main settlement's axis comprises a stream whose flow has been man-regulated.

The settlement is located further from the main urbanization axes of Ružomberok and Banská Bystrica. The settlement is accessible only along a narrow road which crosses Biely Potok and subsequently goes along the Trlenská valley. The settlement's isolation and natural conditions have determined its development as a unique type of a settlement. This was also due to the fact that Vlkolínec wasn't affected by the construction boom of the 19th and 20th century and due to several fires from which the settlement suffered during this period. At present, the settlement represents the most preserved urban unit of original folk log buildings.

There are 45 preserved wooden homesteads in the settlement. They comprise dwelling-houses together with some economic buildings which are situated in their backyards. There are also two brick houses built in the second half of the 20th century (Svrček et al., 2014). More than half of original houses are three-room houses, the rest are two-room, semi-detached houses with a joint entrance hall and a side chamber. The three-room houses have their rooms arranged in a row. The entrance hall is a room situated in the middle of the house and its back part is used as a kitchen. The entrance hall also serves as the entrance to the other room or a storage room (Bišt'an, 2008).

Vlkolínec reached its peak in between the second half of the 18th century and the second half of the 20th century. During this period, there were very satisfactory conditions for settlement of the mountainous area, which it is typical for. The settlement was quite independent and consumed its own production (Babál et al., 2000).

\section{Historical Landscape Structures of VIkolínec}

Historical landscape structures comprise a set of elements and phenomena in the country which have arisen through intense activity of people over the course of history, and through which people transformed nature or created new, preserved structures (Štefunková et al., 1998).

They represent specific, time-bound and spatially constantly shrinking landscape structures. They are a relic of anthropic activities that have survived until present time. They were the main reason why Vlkolínec was inscribed on the UNESCO World Heritage List. Two types of historical landscape structures - architectural and agricultural - are characteristic for Vlkolínec.

Architectural historical structures. Wooden log buildings are directed towards the stream and towards the communication. Walls of the wooden houses are logs of partially or fully drawn beams, horizontally laid on themselves and caulked. The equalization of steep slopes has been solved by a relatively high stone mantle. However, most of the surviving buildings date from the 19th century. These include 43 nearly 
intact homesteads that retain a multitude of archaic building elements, all set within a traditional farming landscape of strip fields that have become vulnerable due to changed way of life (Figure 6 and 7).

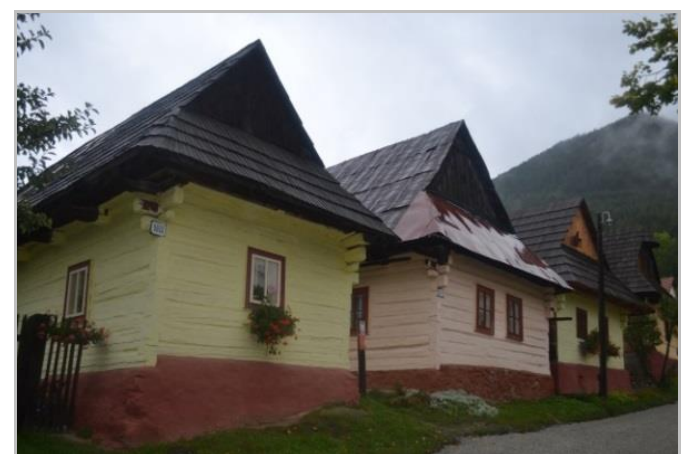

Figure 6. The wooden log buildings Source: authors

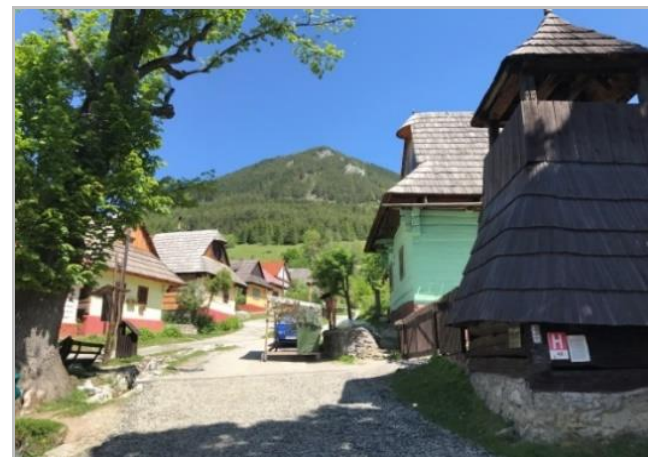

Figure 7. The street of Vlkolínec Source: authors

$\triangleright$ Besides the log houses, other noteworthy buildings are the Church of the Visitation of the Blessed Virgin Mary built in 1875, a bell tower built in 1770, a well, cemetery and a school (Figure 8).

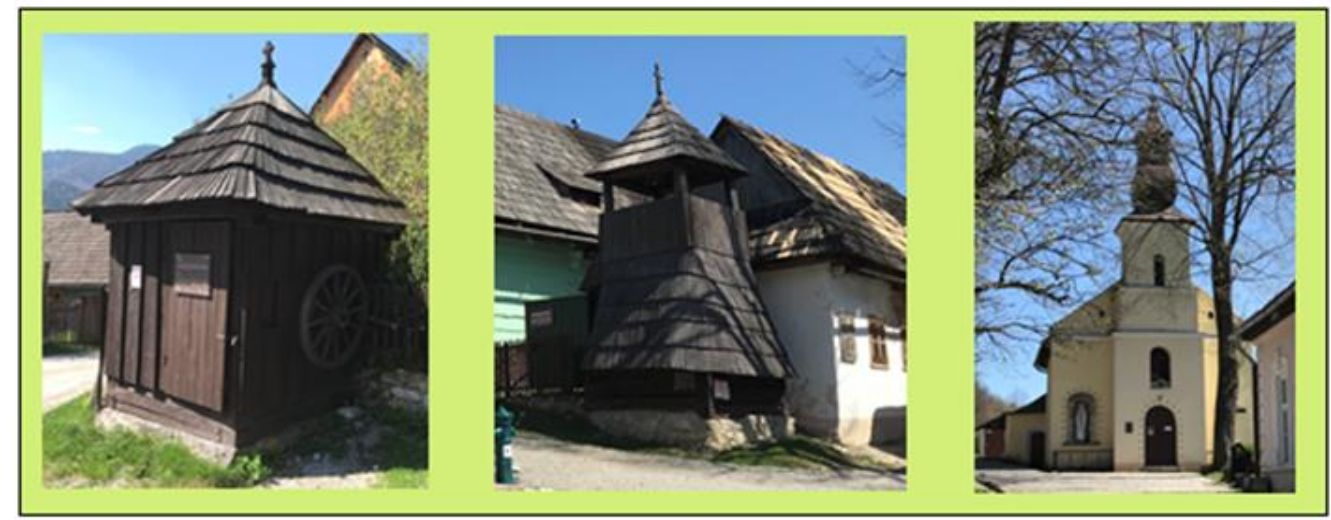

Figure 8. The well, bell tower and the church Source: authors

$\triangleright$ Rod haylofts are located on higher meadows around Vlkolínec. It is estimated that at the time of the greatest development of the settlement, there were around 60 of them in its background (Babál, 2002). 


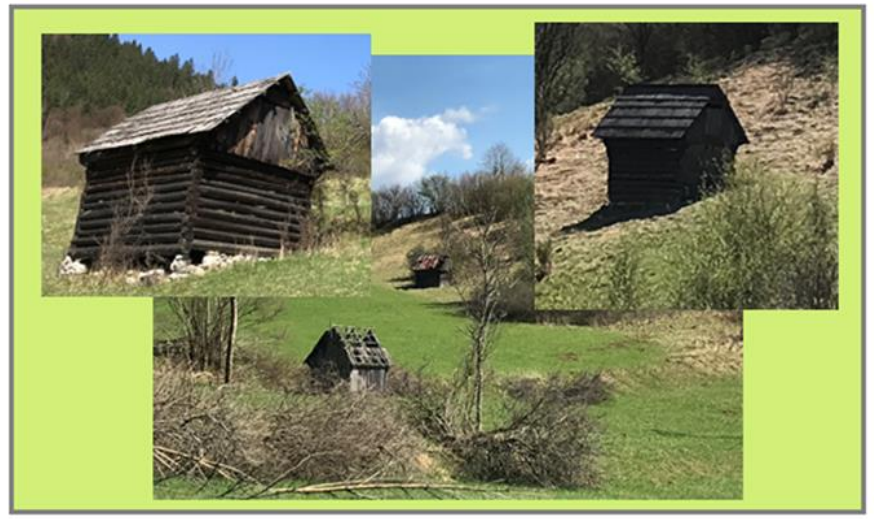

Figure 9. Hayloft in the surroundings of Vlkolínec (Source: authors)

Currently, the haylofts no longer fulfil their function, many of them have already disappeared and those that have survived are in poor condition (Figure 9).

\section{Agricultural historical structures are presented at several occasions.}

$>$ Gardens located in the immediate vicinity of dwellings, near economic buildings.

$\triangleright$ A homogeneous set of meadows and pastures, for which limitations for unification of agricultural land were removed in the 1970s.

$>$ Complex terraced terrain arrangement with meadows divided by vegetation in parallel lines. It is the consequence of preserved alternate farming, expressing the primary use of land, and is therefore considered to be one of the most valuable elements (Figure 10).

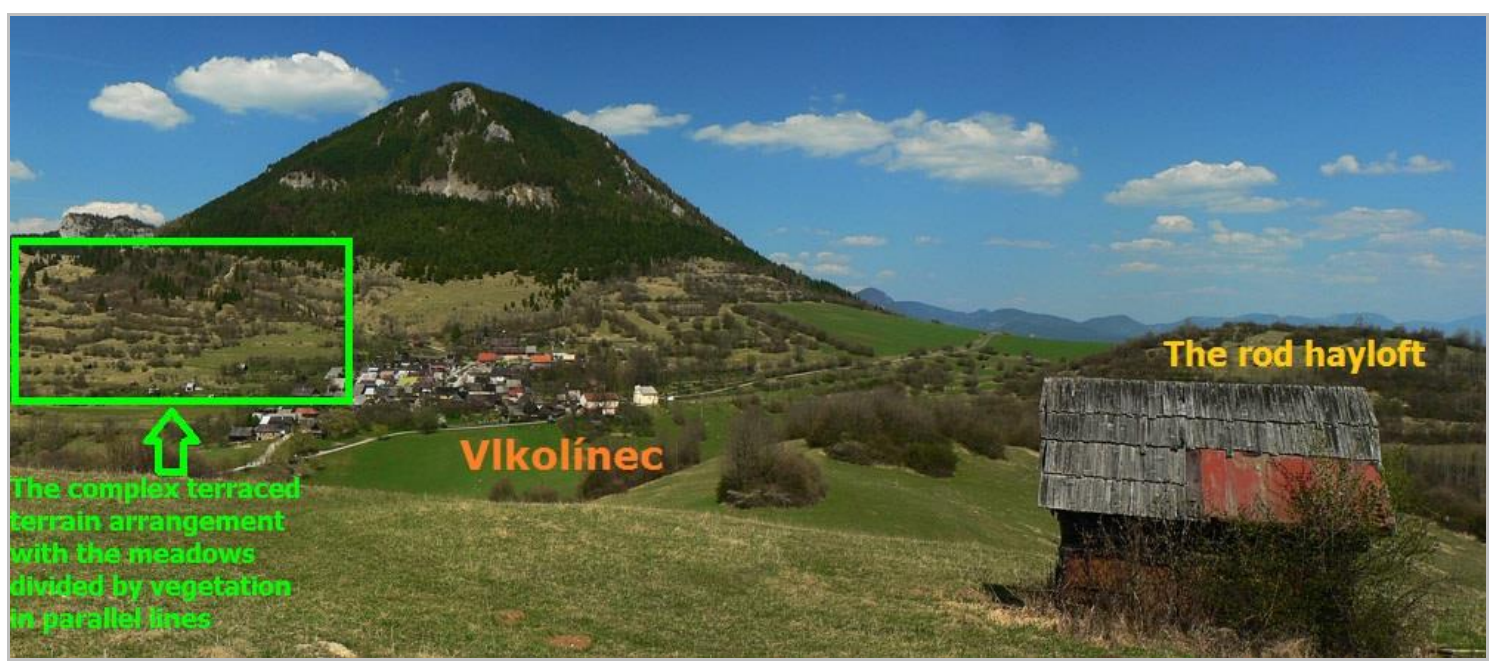

Figure 10. The complex terraced terrain arrangement (Source:

http://turistika.vetroplachmagazin.sk/sidorovo-533)

\section{Analysis of Students' Knowledge about UNESCO World Heritage Site of Vlkolínec at Primary Schools in the Liptov Region}

As mentioned in the section on methods, knowledge of students was tested in a questionnaire with 8 questions. 
The first question enquired about the students' interest in this locality. Vlkolinec was visited more than once by $22.8 \%$ of the respondents and it was visited only once by $34.4 \%$. Out of the $42.8 \%$ who did not visit Vlkolínec, $26.7 \%$ did not even want to visit it and $16.1 \%$ have not visited it yet, but are interested in going there. This finding shows that more than half of the pupils (57.2\%) who participated in the survey have already visited Vlkolínec (Figure 11).

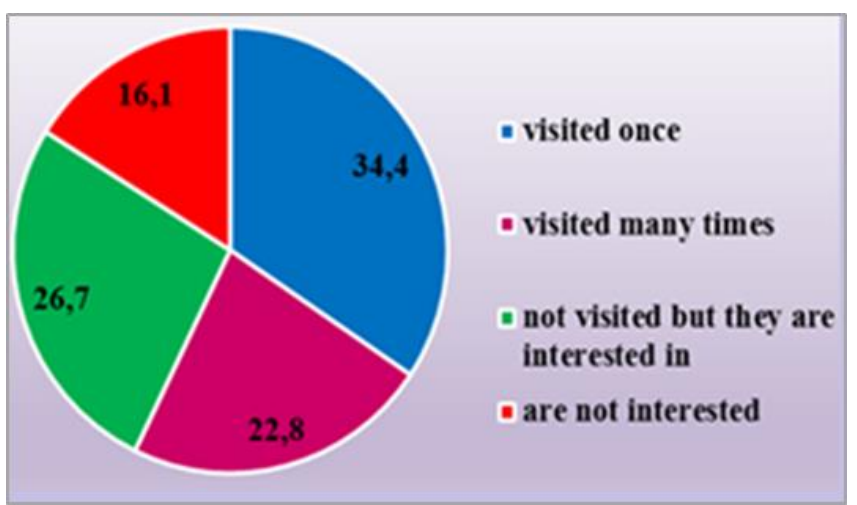

Figure 11. Answers to question 1 Author's processing

In the second question, the students were asked to assign Vlkolínec to the correct district (NUTS 4, LAU1). Vlkolínec was correctly assigned to the district of Ružomberok by $86.7 \%$ of respondents. The rest chose the option that Vlkolínec is located within the district of Liptovský Mikuláš, which is also located in the Liptov region, and some of the students lived in it at the time. The third question focused on the students' familiarity with the typical architecture of Vlkolínec by means of pictures. Students were presented three pictures from which they had to choose one with characteristic houses located in Vlkolínec. The correct picture was identified by $71.1 \%$ of students. The fourth question was designed to find out whether the students knew the reason for the inscription of Vlkolínec on the List of UNESCO World Heritage Sites (54.3\% of students responded correctly - and $45.7 \%$ of students incorrectly).

Most of the incorrect answers (21.4\% of students) thought that the reason for the inscription of Vlkolínec on the UNESCO World Heritage List was the Church of the Visitation of the Blessed Virgin Mary. The second largest group of incorrect answers marked the well and the bell tower as the reason for the inscription of Vlkolínec on the List of UNESCO World Heritage Sites (12.3\%) and $11.8 \%$ marked the existence of orchards near the houses to be the reason for its inscription (Figure 12). 


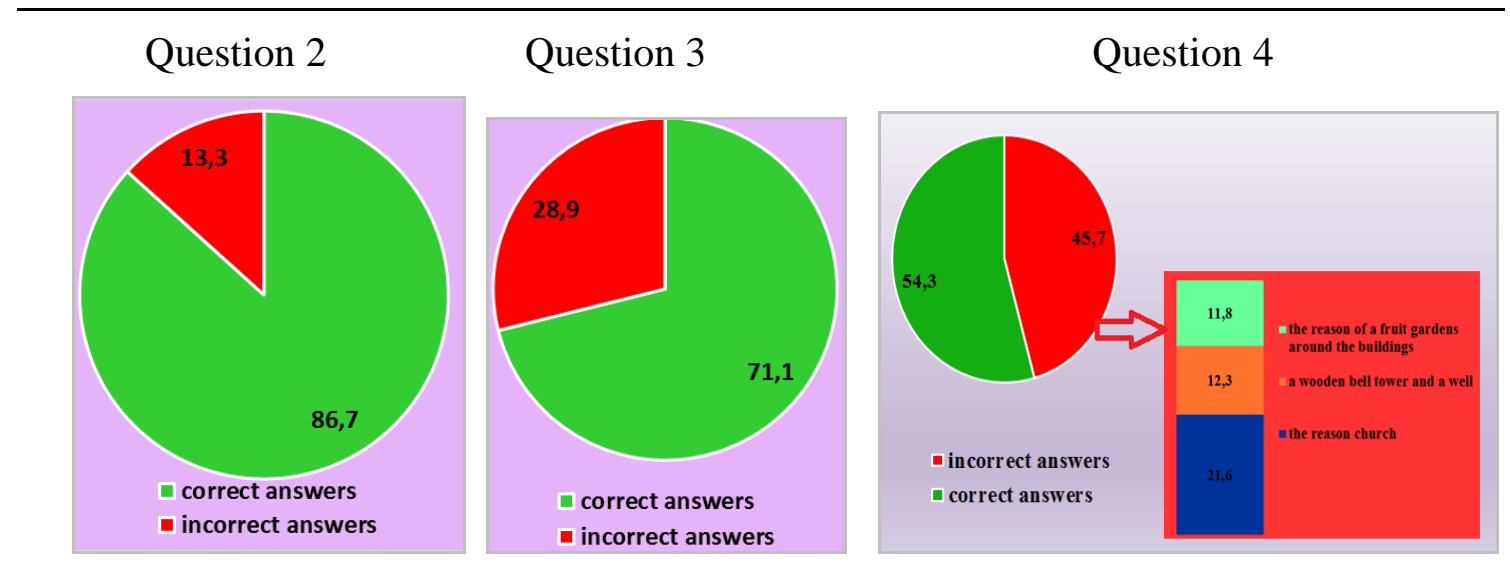

Figure 12. Answers to questions 2, 3 and 4 Author's processing

The fifth question asked if the pupils knew the hill below which Vlkolínec is located. Only $41.7 \%$ of pupils answered correctly. In the sixth question, the pupils had three options to choose the typical roofing of houses that determines the typical appearance of houses at the site. The options were shingle, tile, and sheet metal (28.9\% of pupils answered correctly). The seventh question aimed to find out whether the pupils knew that Vlkolínec is a living settlement with its inhabitants, not an open-air museum. Only $53.3 \%$ of pupils answered correctly. And finally, the last - eighth question was focused on finding out about the pupils' knowledge of the way of life in Vlkolínec, which led to the current status of Vlkolínec as a UNESCO site. Only $21.1 \%$ answered correctly, and answered land management in mountainous environments.

Question 5

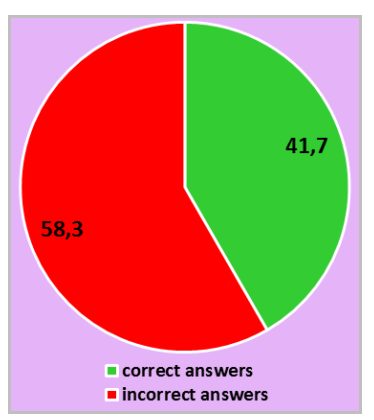

Question 6

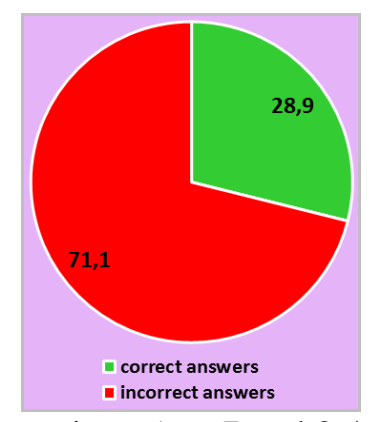

Question 7

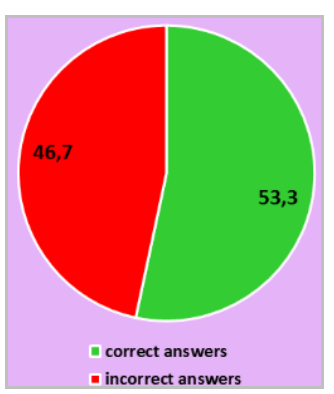

Question 8

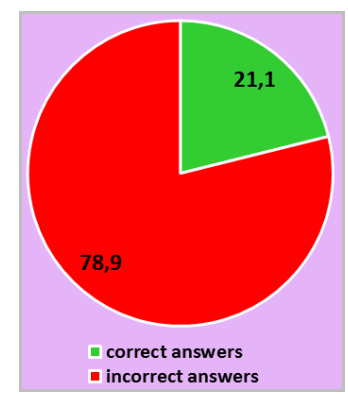

Figure 13. Answers to questions 5, 6, 7 and 8 Author's processing

\section{Finding - Proposed Activities on the Slovak UNESCO World Heritage Site Of Vlkolínec}

Although correct answers dominated over incorrect ones, we expected the students to do better. This also supported a belief that little attention is paid to UNESCO sites in the local region as well as within Slovakia.

Geography of the Slovak Republic is presented in more detail to Year 8 Slovak students at primary schools. Here, the students are given more space to get acquainted not only with Vlkolínec, but also with all Slovak sites inscribed on the World Heritage List. At the end of the course, there is a chapter devoted to the local landscape which provides an ideal space for inclusion of excursions and project teaching on appropriately 
chosen topics. Therefore, we decided to design and organize activities in the Liptov region to support students' interest in the only UNESCO site in their region. A good way to acquire the desired knowledge is to visit the site and with respect to the curriculum is the most appropriate organizational form in this case was a one-day excursion to Vlkolínec. We decided to apply project teaching to validate the acquired knowledge.

\section{Geographical Excursion to Vlkolínec}

Geographic excursion is an organizational form of experience-based learning that creates a new direct experience for students. Teaching Geography in the classroom, only with textbooks and maps, may not be interesting for students since they do not have the opportunity to engage their senses in learning. It is the geographical excursion that enables students to perceive objects and phenomena directly in their natural environment and, at the same time, it gives passive students the opportunity to engage in the learning. It makes use of specific teaching methods, especially geographic observation, practical work, individual task solving, explanation, interview, collection of background material and data, etc. Students gain a lot of knowledge and experience, especially on the basis of direct observation of various things, events and phenomena in their natural environment. Excursions also have a very important educational significance. Students gradually acquire a positive attitude towards the analysed territory and are aware not only of the importance of mutual cooperation among people but of the importance of the results of human work. Students also acquire a wealth of aesthetic experiences through direct contact with nature and visiting various monuments, buildings etc. And last but not least, the importance of excursions in building a positive attitude towards the local region is irreplaceable, and therefore, the regional approach also needs to be emphasized. This very attitude enables connection and application of theoretical knowledge of the country to its practical use, which means the country and region students know (Križanová, 2001).

The main objective of the proposed excursion was to strengthen students' interest in Local landscape Geography and to provide them with basic knowledge about Folk Architecture Monument Reservation and the UNESCO World Heritage Site of Vlkolinec in Slovakia. The students learned about the history of the settlement, how people used to live there and what they used to do. They also met and visited the landmarks of the area of interest.

Various teaching methods, such as observation, lecture, interview, or demonstration, were used during the excursion. While preparing and conducting the geographic excursion to Vlkolínec, we followed a procedure that, in accordance with Turek (2014), has three basic stages: preparatory, performance and final (A-C), while the first and the last stage take place at school:

The preparatory stage of geographic excursion. The teacher's preparation was extremely important for achieving the chosen objective. Connection of the school topic of study with reality was important for the organization of the excursion. For this very reason, we realized the excursion with Year 8 students who study the topic of UNESCO World Heritage sites in Slovakia within Geography of the Slovak Republic. 
In order to reach the set objective and to acquire the required knowledge, it is important to prepare the excursion properly. That is why we clearly defined the content and objective of the excursion, and accordingly, we conducted detailed preparations. The teacher's overall preparation consisted of organizational and professional planning.

Organizational planning by the teacher:

- selection of the excursion route (Figure 14),

- teacher conducts a pre-visit, plans the content and extent of the excursion,

- selection of observation objects,

- design of activities and tasks for students,

- arranging the date and time (1 day in June);

- preparation of the necessary tools,

- familiarizing students with the excursion.
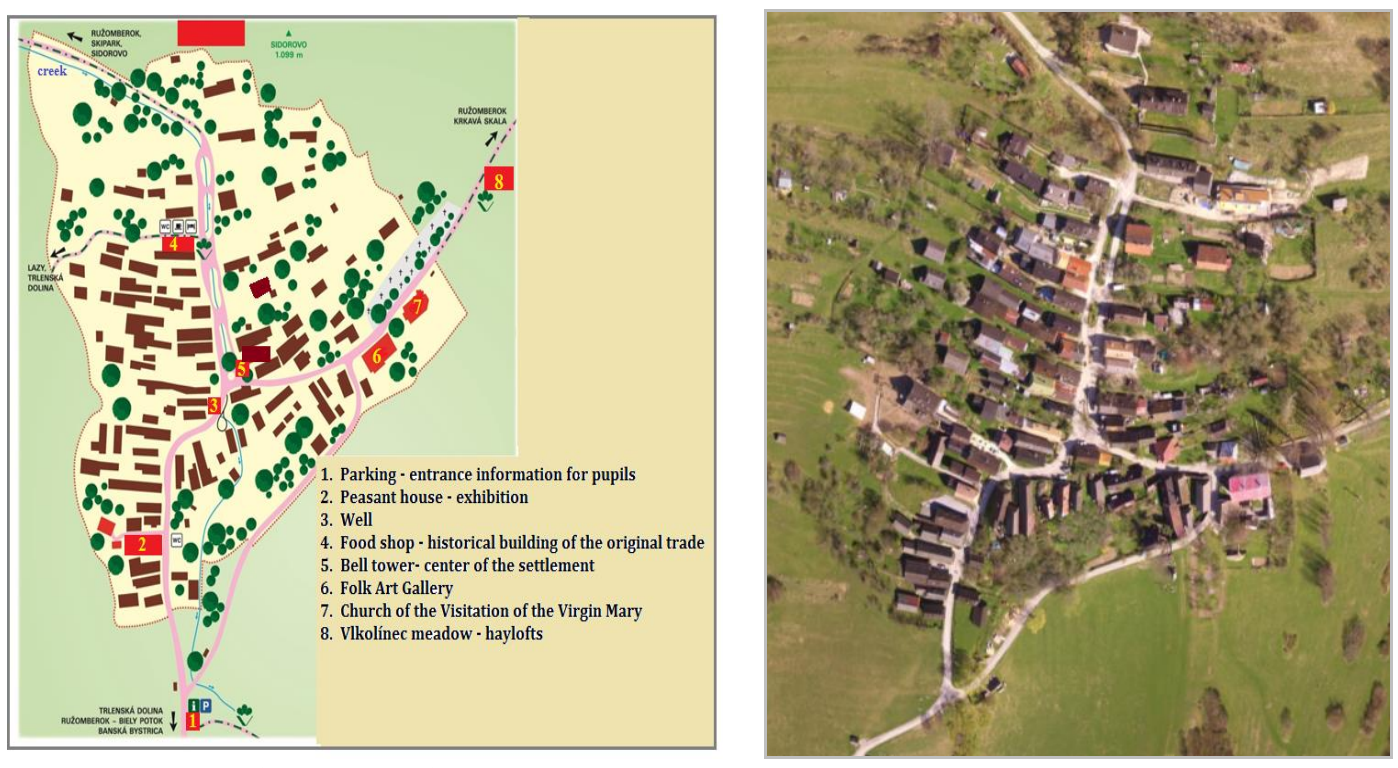

Figure 14. Excursion plan edited by the authors

The excursion route consisted of 8 stations (Figure 14):

1. Parking - entrance information for students

2. Peasant house - exhibition

3. Well

4. Food shop - historical building of the original trade

5. Bell tower - the center of the settlement

6. Folk Art Gallery

7. The Church of the Visitation of the Blessed Virgin Mary

8. Vlkolínec meadow - hayloft

Professional planning by the teacher:

- studying the curriculum in a textbook, getting familiar with the concepts that students are supposed to master,

- collecting professional literature covering the chosen location,

- designing the excursion plan and its publication on the classroom notice board. 
In addition to the teacher's preparation, it was also necessary to prepare students for the excursion. It included familiarizing students with the course and objective of the excursion, providing basic information on its course (date, means of transport, safety measures, suitability of clothing, a list of tools students are supposed to bring with them, etc.), curriculum revision and practicing the students' skills according to the theme and focus of the excursion - for the particular excursion to Vlkolínec, we used a worksheet focused on the UNESCO World Heritage Sites in Slovakia.

The performance stage of the geographic excursion. It consisted of two types of learning activities, namely:

Pre-visit activities. We checked the number of students and tools that the students needed for the excursion (territory map, pen, notebook, colored pencils).

Activities at particular stations. Various teaching methods, such as observation, lecture, interview or demonstration, were used during the excursion. We wanted the students to focus not only on observing important objects, phenomena and processes. We constantly communicated with the students, responded to their questions, emphasised various attractions and stimulated students' curiosity and activity. The lecture was sufficiently concise, brief, and comprehensible (Tomčíková, 2005).

On the basis of predetermined tasks, the students continuously recorded the acquired information into worksheets, also conducted various kinds of observations, collected plants (herbs from Vlkolínec - some of the most active students made a herbarium), drew sketches and took photographs.

The main students' activities during the excursion in Vlkolínec:

- marking the particular stations in the plan of Vlkolínec, making notes,

- drawing a sketch of a typical house in Vlkolínec,

- collecting and naming flowering plants typical for the Vlkolínec surroundings,

- performance of activities that the inhabitants of the settlement of Vlkolínec used to do in the past (carpet weaving, waving, pottery, breeding and pet care).

The students also visited some buildings, such as the Farmer's house, the Gallery, or the economic building of one of the female inhabitants of the settlement of Vlkolinec, as well as the dominant features of the settlement, such as the Church of the Visitation of the Blessed Virgin Mary, the well and the bell (Figure 8).

The final stage of the geographic excursion. It included the evaluation and processing of its results, as well as the interpretation of the collected information. It was very important to consolidate the students' knowledge of the UNESCO World Heritage Site of Vlkolínec and to incorporate it into the knowledge gained in the previous lessons but also outside of school. Consequently, the students were able to use the acquired knowledge and their outcomes (sketches, drawings, worksheets) in a follow-up project.

\section{The Project: VIkolínec - UNESCO World Heritage Site in Slovakia}

One of the ways to actively engage students in the educational process is to include project teaching in the learning process. The main teaching method is the project method, in which students develop a project under the guidance of a teacher. 
By using this method in lessons, the teacher leads their students to fully develop their independence, creativity and responsibility. In project teaching, it is possible to develop communication skills and competences such as written communication, searching for specific information and creating new information. Another competence is the ability to work in a team if making use of group work. The ability to work with modern information technologies is currently one of key competencies, as knowing how to use personal computers, the Internet, and a variety of information resources is a prerequisite for getting a lot of information when developing suitable projects (Tomčíková 2018).

While developing the project, we followed a procedure that in accordance with Turek (2014) respects four basic stages (1-4):

Selection of the project theme. It based on the results of the survey, we designed and conducted a project on the UNESCO World Heritage Site of Vlkolínec in Slovakia with the Year 8 students at primary school. In selecting the project theme, we also took into account the students' needs and interests. It is highly recommended that the project is related to the students' out-of-school experience and is based on their experiences. It should be a bridge between school and life, it should not be artificially made for obligatory curriculum. Therefore, before the project itself, we organized a geographic excursion to Vlkolinec for these students.

A desired prerequisite for the project teaching is the internal motivation of students, so the development of the project should lead to particular results when the learner acquires new knowledge on its basis. By developing this project, the students learned about the UNESCO World Heritage Site of Vlkolínec, which is located in their local landscape. Therefore, this project is a part of the lessons focused on Local landscape Geography. We also used cross-curriculum relationships between Geography and Art.

Planning of the project development. The timetable for the project was set for June - the last month of the school year. In the preparatory stage of the project, we designed an excursion to Vlkolínec - as one of important organizational teaching forms in Geography. Then we conducted the project development in two Art lessons and one Geography lesson. The outcomes were two large posters: Vlkolínec - a map created by students and the main symbols of Vlkolínec.

The project development. The first stage of the project was a one-day geographic excursion to Vlkolínec. Then the actual development of the project continued at school. In an Art lesson, some students drew the historical landscape structures of Vlkolínec - architectural (a well, a bell tower and a church, hay lofts) and agricultural (gardens, the terraced terrain, an arrangement with the meadows divided by vegetation in parallel lines). Together, they selected the most beautiful pictures and stuck them on A0-sized paper. They printed the labels on PC and stuck them to the matching pictures. Finally, they drew the coat of arms of the settlement and added the name of the poster: Vlkolínec - a UNESCO World Heritage Site.

In the next Art lesson, the students drew the houses of Vlkolínec as they remembered them from the excursion and using notes from the excursion. They also had an opportunity to see a prepared presentation with photos of typical houses in Vlkolínec. 
Historical photos of the settlement were also available. Historic postcards and photographs have a significant and yet "undiscovered" potential for the research of historical landscapes (Weis, Hronček, 2017). Various art techniques (painting, drawing, etc.) could be used to create the pictures. One student drew the main road network of Vlkolínec with the help of the plan of Vlkolínec and the teacher's and other classmates' notes. Then the students stuck the main landmarks - a well, a bell tower and a church. Finally, each pupil stuck their house along the road network. The teacher's role was of an assistant, facilitator and a counsellor.

Publication of the results of the project development. In a Geography lesson, the students revised the basic information about Vlkolínec with the help of the teacher and posters (Figure 16) and then they hung the posters up in the classroom to remind them of the excursion and the knowledge gained during the project development.

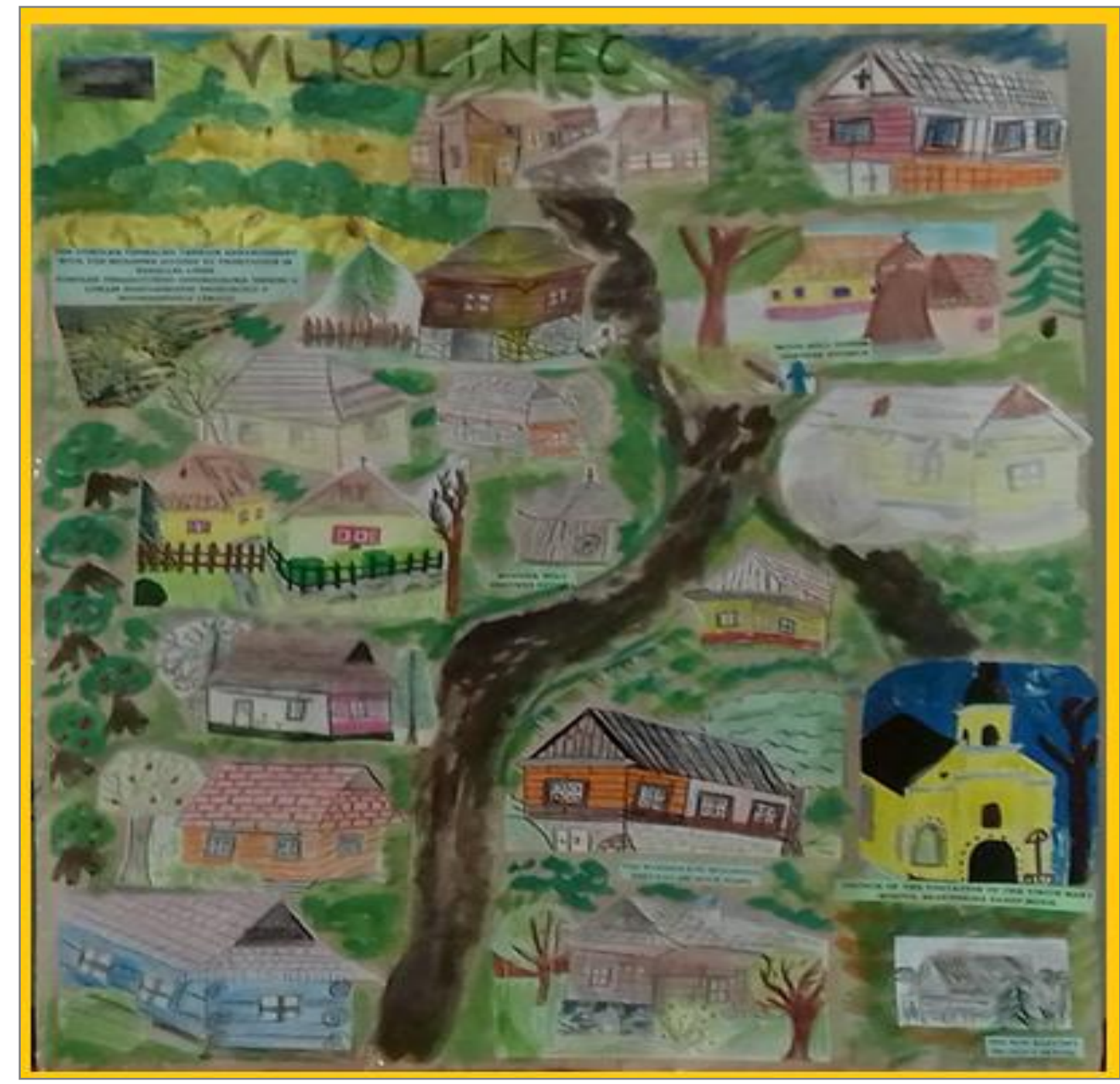

Figure 16. Poster of Vlkolínec (Source: pupils) 


\section{Discussion}

We organized a one-day geographic excursion to Vlkolínec for 30 pupils in primary school in Ružomberok (Klačno). Afterwards, work on the project continued at school. In an Art lesson, some students drew the historical landscape structures of Vlkolínec architectural (a well, a bell tower and a church, hay lofts) and agricultural (gardens, the terraced terrain, an arrangement with the meadows divided by vegetation in parallel lines). Together, they selected the most beautiful pictures and stuck them on A0-sized paper. They printed the labels on PC and stuck them to the matching pictures. Finally, they drew the coat of arms of the settlement and added the name of the poster: Vlkolínec - a UNESCO World Heritage Site. In the next Art lesson, the students drew the houses of Vlkolínec as they remembered them from the excursion and using notes from the excursion. They also had an opportunity to see a prepared presentation with photos of typical houses in Vlkolínec. Various art techniques (painting, drawing, etc.) could be used to create the pictures. One student drew the main road network of Vlkolínec with the help of the plan of Vlkolínec and the teacher's and other classmates' notes. Then the students stuck the main landmarks - a well, a bell tower and a church. Finally, each pupil stuck their house along the road network. In a Geography lesson, the students revised the basic information about Vlkolínec with the help of the teacher and posters.

At the next Geography lesson, the pupils, who took part in the excursion and then made the poster, filled the same questionnaire where answered questions 2-8. (It was the sample of 30 pupils - one class, they were from the set of pupils, they were tested -see analysses.).

The results are shown in graphs below (Figure 17). We have seen a significant improvement in responses across all questions.

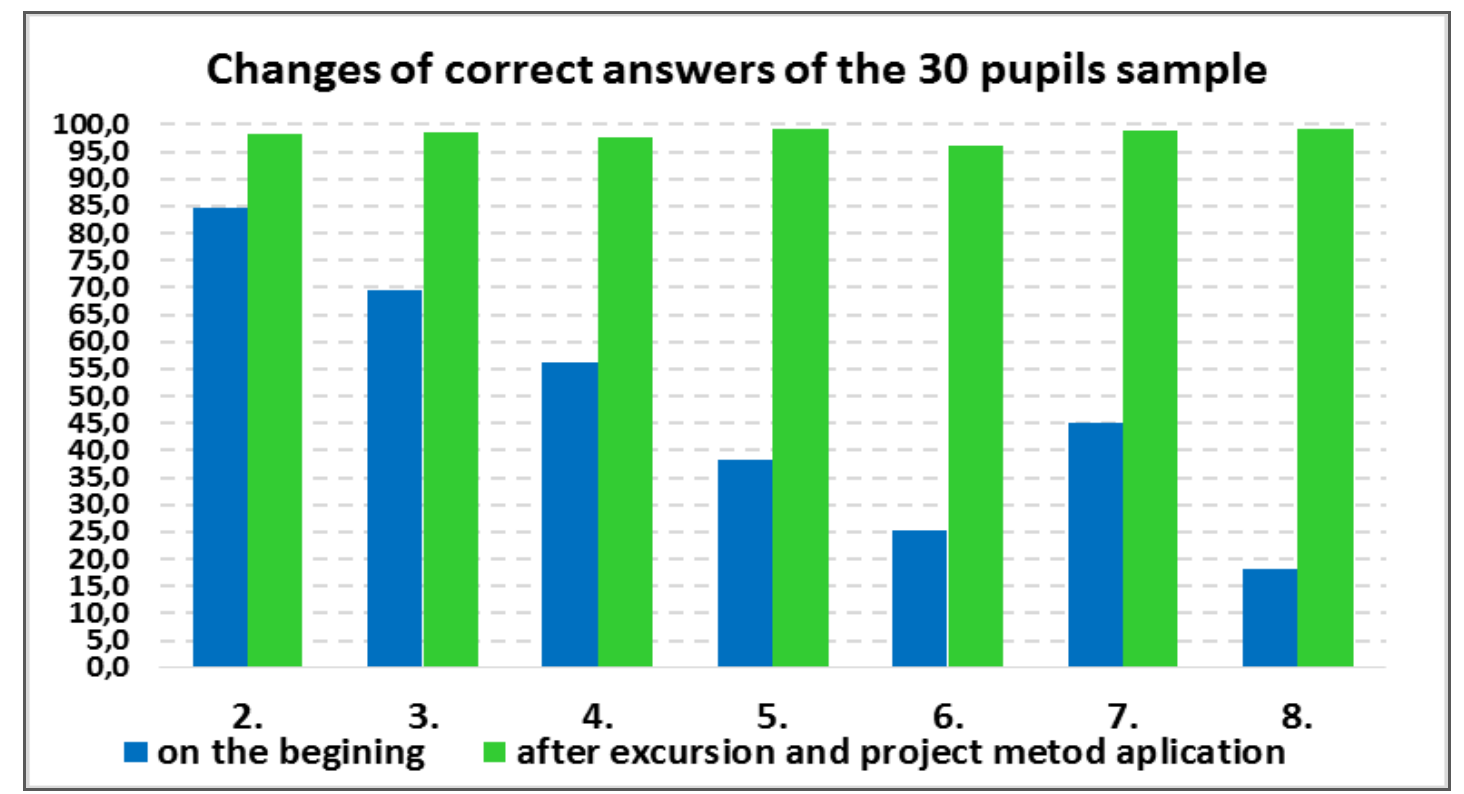

Figure 17. Changes of correct answers in percent's of the 30 pupils' sample (Source: authors) 
We can conclude that the use of experience-based learning had a positive effect on students. We have proven, that some of its many strengths are highly motivating, creative. It develops social feeling (students' cooperation, the ability to put forward their own opinions but also accept the opinions of others) and strengthens aesthetic feelings.

\section{Conclusion}

Vlkolínec belongs to the oldest Slovak sites that have been inscribed on this list. In the Liptov region, it is the only UNESCO World Heritage site. Therefore, it is important for the students (as well as for adults) to know basic information about this UNESCO World Heritage site as well as the reasons for its inscription.

Nowadays, the role of the teacher is not to mediate the knowledge but to bring pupils to desire to learn and to teach them to learn effectively. The skills also include motivation for education and self-education. If we want to motivate a student, we need to create suitable conditions and environment. We assume that if students actively participate in the learning process where they find their own self-realization, there are situations that should stimulate the students' interest in learning and their own progress. Experience-based learning is certainly a more effective form of students' personal development than teaching in a traditional, sometimes dogmatic system of education.

A great challenge for a teacher is to create such an environment in lessons so that students get more active and creative. The role of the teacher in active teaching, compared to traditional teaching, is changing significantly. The teacher does not provide the students with the complete knowledge, but he or she becomes a co-developer of the project and the students' coordinator. The role of the teacher is to create such a situation in which the student understands the need for new knowledge and to create a situation that enables the student to discover new things on their own. This enables development of new relationships between the student and the teacher. The teacher and the student become partners who jointly create a piece of work for which they take responsibility.

\section{References}

Babál, M. (2002). Wooden village vlkolinec. Ružomberok, p. 312 (in Slovak)

Bišt'an, M. (2008). Vlkolínec a short history, architecture and life. Ružomberok, 20 p. (in Slovak)

Dzuriak K. et al. 2014. Biely Potok, Vlkolínec. TESFO Ružomberok. 327 p. (in Slovak)

Gullino, P., Larcher, F. (2013). Integrity in UNESCO world heritage sites. A comparative study for rural landscapes. Journal of Cultural Heritage, Volume 14, Issue 5, 2013, Pages 389395, ISSN 1296-2074, https://doi.org/10.1016/j.culher.2012.10.005.

Hudeková, Z. et al. (2009). Management plan of the monument reservation of folk architecture vlkolinec. (in slovak) (Accessed online 20 April 2018). Retrieved from https://www.pamiatky.sk/Content/Data/File/unesco/Vlkolínec_A5_final_20_5_2009.pdf

ISCED (2014). Geography for primary school in Slovak republic. Retrieved from http://www.statpedu.sk/files/articles/dokumenty/inovovany-statny-vzdelavaciprogram/geografia_nsv_2014.pdf?fbclid=IwAR08ulg5rGDjnzXIIgN56hMSEJjZRh9wW ABtUvn1xFsycg62sPEMRkT2S4k 
Koca, N., \& Yıldırım, R. (2018). Relationship between geography-tourism and tourism's effects according to high school students. Review of International Geographical Education $\begin{array}{lllll}\text { Online (RIGEO), } & 8 & \text { (1), 26-52. } & \text { Retrieved from }\end{array}$ http://www.rigeo.org/vol8no1/Number1Spring/RIGEO-V8-N1-2.pdf

Križanová, I. (2001). Assessment of geographic knowledge of elementary school pupils about the local region on the example of Banská Bystrica district. Acta facultatis rerum naturalium Universitatis Mathias Bell. Geographical studies (8). Banská Bystrica: 309315.

Plesník, P. (2002). Phytogeographical and vegetation divisions. Atlas of the Slovak Republic. Slovak environment agency. Banská Bystrica. 344 p.

Rakytová, I. (2018). European Union in the practical life of primary school pupils (at the 2nd level of primary schools in Slovakia): Useful Geography: Transfer from Research to Practice, Proceedings of 25th Central European Conference, Masaryk University, Brno. 65-81. Retrieved from https://munispace.muni.cz/index.php/munispace/catalog/book/997

Štefunková, D., \& Dobrovodská, M. (1998). Cultural and historical resources of Slovakia and their importance for sustainable development. Izakovicová, Z., Kozová, M., Pauditsová, E. (eds.): Implementation of the Sustainable Development. Smolenice: The Institute of Landscape Ecology of SAS: $104-111$.

Svrček, P. et al (2008): Vlkolínec, short history, architecture and life. Ružomberok, ISBN 97880-969976-2-6.

Svrček, P. et al. (2014). Biely Potok - Vlkolinec. Ružomberok, 327 p. (in Slovak)

Tomčíková, I. (2005). Field trip and excursions to local region in teaching of geography and homeland and nature study in primary school. Disputationes Scientificae Universitatis Catholicae in Ružomberok. 5 (1). 74-81.

Tomčíková, I. (2018). Experience-based learning in teaching of the local landscape, Svobodova, H.: Useful Geography: Transfer from Research to Practice, Proceedings of 25th Central European Conference, Masaryk University, Brno: 91- 102.

Tomčíková, I., \& Rakytová, I. (2018). Geography of local landscape in the educational process in primary schools in Slovakia. European journal of geography, 9 (1), 49-61

Turek, I. (2014). Didactics. Wolters Kluwer, Bratislava, 620 p.

UNESCO (2019). World Heritage. Retrieved from http://whc.unesco.org/en/about

Weis, K., \& Hronček. P. (2017). Using historic postcards and photographs for the research of historic landscape in geography and the possibilities of their digital processing. In The European Journal of Geography. 8 (5): 77-85.

\section{Biographical Statements}

Iveta RAKYTOVÁ is assistant professor at the Department of Geography, Faculty of Education, Catholic University in Ružomberok, Slovakia. She focuses on social geography, geography of tourism and didactic of geography.

Ivana TOMČÍKOVÁ is assistant professor at the Department of Geography, Faculty of Education, Catholic University in Ružomberok, Slovakia. She focuses on physical geography, geography of tourism and didactic of geography. 